\title{
Studies on blood T and B lymphocytes in rheumatoid arthritis
}

\author{
A. MICHELI AND JACQUELINE BRON \\ From the Institute of Physical Medicine and Rehabilitation, University of Geneva, Switzerland
}

Lymphocytes, important in immune mechanisms, have been studied in several human clinical states where these mechanisms are thought to be involved (Pincus, Bianco, and Nussenzweig, 1972; Stjernswärd, Jondal, Vánky, Wigzell, and Sealy, 1972; Wybran and Fudenberg, 1973), particularly in rheumatic diseases (Frøland, Natvig, and Husby, 1973; Keith and Currey, 1973; Papamichail, Brown, and Holborow, 1971; Williams, DeBord, Mellbye, Messner, and Lindström, 1973). In the human, lymphocytes of $\mathbf{T}$ and $\mathrm{B}$ type have distinct markers. T-cells form rosettes after incubation with fresh, unsensitized sheep red blood cells (SRBC-rosettes; Bach, Dormont, Dardenne, and Balner, 1969; Coombs, Gurner, Wilson, Holm, and Lindgren, 1970; Jondal, Holm, and Wigzell, 1972), whereas B-cells are usually recognized either by surface immunoglobulins (Papamichail and others, 1971) or by the presence of a receptor for complement (Bianco, Patrick, and Nussenzweig, 1970).

Reports have been published, sometimes contradictory, about the ratios of $\mathrm{T}$ and $\mathrm{B}$ lymphocytes in circulating blood, and in synovial fluid (Williams and others, 1973; Frøland and others, 1973; Keith and Currey, 1973; Papamichail and others, 1971).

In the present paper, the relative number of $T$ and $B$ lymphocytes was studied in the peripheral blood of three groups: (1) patients suffering from rheumatoid arthritis (RA), (2) patients with other arthropathies, and (3) normal subjects.

T-lymphocytes were characterized by formation of SRBC-rosettes, and B-lymphocytes by formation of 'complement-rosettes'.

\section{Materials and methods}

In the first of the three groups of subjects studied, all 17 suffered from classical or definite RA (A.R.A. criteria); the second group included 19 patients with various, noninflammatory arthropathies; and in the third group were 17 normal subjects (medical and paramedical personnel).

Circulating lymphocytes were isolated by the method of Boyüm (Boyüm, 1968). Repeated controls have shown that 90 to $95 \%$ of the cells prepared by this technique had the morphology of lymphocytes.
For the SRBC-rosette test, lymphocytes (Ly) were incubated with washed sheep red cells in a ratio of $10^{6} \mathrm{Ly}: 10^{7} \mathrm{SRBC}$ in a volume of $0.5 \mathrm{ml}$ (Stjernswärd and others, 1972). After incubation for $15 \mathrm{mins}$ at $37^{\circ} \mathrm{C}$, the mixture was centrifuged at $200 \mathrm{~g}$ for 5 mins and the tubes kept cold overnight. The cells were resuspended by gentle agitation (by hand) for $5 \mathrm{mins}$, and the ratio of rosettes to the total number of lymphocytes was determined.

The complement-rosette test was done according to the method of Stjernswärd and others (1972). Briefly, this consisted of sensitizing washed SRBC with a rabbit antibody to SRBC at a dilution of 1:2000. After washing the sensitized SRBC, human complement was added as whole fresh serum diluted $1: 20$. After $30 \mathrm{mins}$ at $37^{\circ} \mathrm{C}$, three more washings were done in Hanks's balanced salt solution (HBSS) before the cells were mixed $\left(10^{6} \mathrm{Ly}+10^{7}\right.$ SRBC) and centrifuged at $200 \mathrm{~g}$ for 2 mins and then left at room temperature for 30 mins. Most of the supernatant was aspirated and the cells resuspended on a rotator. The rosettes were then counted under low magnification, and related to the lymphocyte count.

To test for the specificity of the complement-rosette (Pincus and others, 1972). SRBC were incubated, after treatment with antibody and with complement, with a Fab fragment of a rabbit IgG antihuman $C 3\left(\beta_{1} \mathrm{C} / \beta_{1} A\right)$. Inhibition of the rosettes by this antibody fragment was considered as indicative of the specificity of the complement-rosette, because in our hands incubation with normal rabbit Fab fragment produced no inhibition. Furthermore, incubation of lymphocytes with SRBC sensitized only with amboceptor, without complement, repeatedly failed to give more than 3 to 5 rosettes/100 lymphocytes.

\section{Results}

The Table shows the results obtained in the two types of rosette tests for the three groups investigated. No statistically significant differences were found among groups for either SRBC-rosettes or complementrosettes ( $\mathrm{T}$ - and B-lymphocytes, respectively).

\section{Discussion}

The results show that, with the techniques used for marking B-cells and T-cells, respectively, no statistically significant difference was found among groups of RA patients, normals, or patients suffering from 
Table Results of rosette tests in 3 groups

\begin{tabular}{|c|c|c|c|c|c|}
\hline \multirow[b]{2}{*}{ Group } & \multirow[b]{2}{*}{ No. individuals } & \multicolumn{2}{|c|}{ Spontaneous-rosettes (T-cells) } & \multicolumn{2}{|c|}{ Complement-rosettes (B-cells) } \\
\hline & & No. tests & $\not{X} \pm s(\%)$ & No. tests & $\not{X} \pm s(\%)$ \\
\hline $\begin{array}{l}\text { Normals } \\
\text { RA } \\
\text { Other diseases }\end{array}$ & $\begin{array}{l}17 \\
17 \\
19\end{array}$ & $\begin{array}{l}18 \\
31 \\
30\end{array}$ & $\begin{array}{l}57 \cdot 6 \pm 12 \cdot 0 \\
63 \cdot 1 \pm 11 \cdot 5 \\
64 \cdot 0 \pm 11 \cdot 5\end{array}$ & $\begin{array}{l}19 \\
33 \\
30\end{array}$ & $\begin{array}{l}26 \cdot 7 \pm 11 \cdot 2 \\
29 \cdot 8 \pm 11 \cdot 1 \\
25 \cdot 1 \pm 12 \cdot 6\end{array}$ \\
\hline
\end{tabular}

noninflammatory arthropathies. This conforms with the results of Keith and Currey (1973), but contradicts those of Mellbye, Messner, DeBord, and Williams (1972) and those of Papamichail and others (1971). Mellbye and others found fewer B-cells (C3-receptor lymphocytes) in RA patients, as compared to normals, whereas Papamichail and others found an increased number of B-cells (surface-Ig), detected by immunofluorescence, among circulating lymphocytes of patients with active RA. Frøland and others (1973), using a different technique, found an increased number of T-cells (SRBC-rosettes) in peripheral blood of RA patients as compared to normals. These authors, however, found $14.8 \%$ of T-cells in normal human subjects as compared to our figure of $57.6 \%$. These discrepancies may be explained either by differences of technique or by a difference in the selection of subjects. More studies will be needed to clarify the question, as well as to develop better standardization of the techniques for marking $\mathrm{T}$ - and B-cells.

\section{Summary}

Lymphocytes were isolated from the blood of subjects forming three groups: 17 patients with rheumatoid arthritis, 19 patients with other arthropathies, and 17 normal subjects. These lymphocytes were characterized as T-cells (sheep red blood cell rosettes) or B-cells (complement-receptor) and the percentage of T- and B-lymphocytes were counted. No statistically significant difference was found among the three groups as to the percentage of T- and B-cells.

\section{References}

BaCh, J. F., Dormont, J., DARdenne, M., AND BALner, H. (1969) Transplantation, 8, 265 (In vitro rosette inhibition by antihuman antilymphocyte serum: correlation with skin graft prolongation in subhuman primates)

Bianco, C., Patrick, R., And Nussenzweig, V. (1970) J. exp. Med., 132, 702 (A population of lymphocytes bearing a membrane receptor for antigen-antibody-complement complexes)

Bоyüм, A. (1968) Scand. J. clin. Lab. Invest., 21, (suppl. 97), 77 (Isolation of mononuclear cells and granulocytes from human blood. Isolation of mononuclear cells by one centrifugation and of granulocytes by combining centrifugation and sedimentation at $1 \mathrm{~g}$ )

Coombs, R. R. A., Gurner, B. W., Wilson, A. B., Holm, G., ANd Lindgren, B. (1970) Int. Arch. Allergy, 39, 658 (Rosette-formation between human lymphocytes and sheep red cells not involving immunoglobulin receptors)

Frøland, S. S., NaTVIG, J. B., AND Husby, G. (1973) Scand. J. Immunol., 2, 67 (Immunological characterization of lymphocytes in synovial fluid from patients with rheumatoid arthritis)

JoNDal, M., Holm, G., AND Wigzell, H. (1972) J. exp. Med., 136, 207 (Surface markers on human T and B lymphocytes. I. A large population of lymphocytes forming nonimmune rosettes with sheep red blood cells)

KeIth, H. I., ANd CurRey, H. L. F. (1973) Ann. rheum. Dis., 32, 202 (Rosette formation by peripheral blood lymphocytes in rheumatoid arthritis)

Mellbye, O. J., Messner, R. P., DeBord, J. R., And Williams, R. C. (1972) Arthr. and Rheum., 15, 371 (Immunoglobulin and receptors for $\mathrm{C} 3$ on lymphocytes from patients with rheumatoid arthritis)

Papamichail, M., Brown, J. C., AND Holborow, E. J. (1971) Lancet, 2, 850 (Immunoglobulins on the surface of human lymphocytes)

Pincus, S., Bianco, C., AND Nussenzweig, V. (1972) Blood, 40, 303 (Increased proportion of complement-receptor lymphocytes in the peripheral blood of patients with chronic lymphocytic leukemia)

StJernswärd, J., Jondal, M., Vánky, F., Wigzell, H., AND Sealy, R. (1972) Lancet, 1, 1352 (Lymphopenia and change in distribution of human $\mathrm{B}$ and $\mathrm{T}$ lymphocytes in peripheral blood induced by irradiation for mammary carcinoma)

Williams, R. C., DeBord, J. R., Mellbye, O. J., Messner, R. P., And Lindström, F. D. (1973) J. clin. Invest., 52, 283 (Studies of T- and B-lymphocytes in patients with connective tissue diseases)

WyBRAN, J., AND FUDENBERG, H. H. (1973) Ibid., 52, 1026 (Thymus-derived rosette-forming cells in various human disease states: cancer, lymphoma, bacterial and viral infections, and other diseases) 